\title{
DÉKÁNY Botond
}

DOI: 10.15170/DIKE.2019.03.02.12

hallgató, demonstrátor

PTE ÁJK

\section{Amikor a naplók valóban megszólalnak}

\section{Gondolatok Kunt Gergely Kipontozva... című művéről ${ }^{1}$ és Bicskey Erzsébet naplójáról ${ }^{2}$}

Általában igaz a naplóírás műfajára, hogy az író nem az utókornak, de még csak kora kíváncsi szemeinek sem szánja művét. A naplóírás célja többek közt az önelemzés, az ember saját magával megejtett eszmecseréje. Hasznos lehet az emlékezésben, a későbbi döntéshozatalban, így az egyén karakterfejlődésében. Amire pedig esetünkben természeténél (őszinteség) fogva alkalmas, az egy fantasztikusan izgalmas, új nézőpont biztosítása történelmünkkel, múltunkkal kapcsolatban.

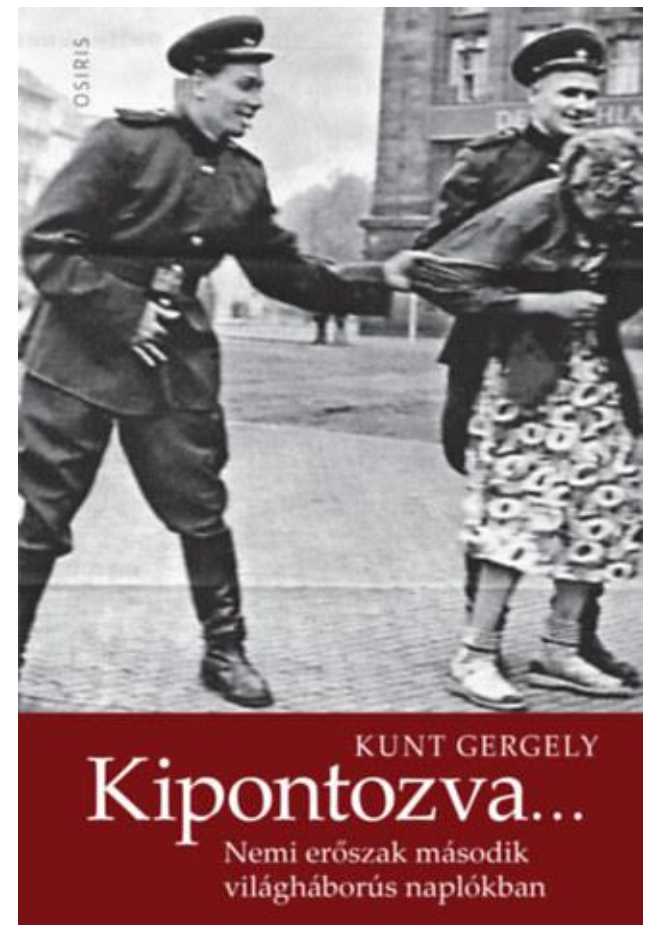

A Kunt Gergely által gyüjtött naplók ${ }^{3}$ tanúsága és Bicskey Erssébet, az Angolkisasszonyok Nyíregyházi Női Felsőkereskedelmi Iskolájában érettségiző fiatal lány naplója több mint alkalmas azon tétel ellenpontozására, mely szerint a történelmet a győztesek írják. Mert államok, szövetségeik konfliktusai, fegyveres összeütközései ugyan eldönthetők, sốt az utókor szól is hadvezérekről, hatalmakról, akik győzelmet arattak. Ugyanez az utókor azonban megkérdőjelezi és megítéli az agresszorok motivációit. Ugyanakkor bármily sérelem (legyen az egyéni, nemzeti), még ha végül megtorolt is, bármily reménylett előny (területi, gazdasági), még ha elnyert is, komolyan mérlegre tétetik e naplósorok fényénél, melyek az érte fizetett árról tanúskodnak.

E tanúvallomások vádlottja pedig a belőlük kirajzolódó összkép láttán elsősorban nem is az áldozatok egyes sérelmeinek okozói (legyenek azok szovjet katonák

\footnotetext{
${ }^{1}$ KunT Gergely: Kipontozva... Nemi erőszak a második világháborús naplókban. Budapest 2019, 240 pp.

2 „Belső Várkastély” Bicskey Erzsébet, egy fiatal lány naplója 1940-1946. Szerkesztette, a kísérőtanulmányt írta, a szöveget gondozta és magyarázatokkal ellátta: KÁNTÁs Balázs - KUNT Gergely - SZABÓ Piroska - SZERÉNYI Ildikó. Nyíregyháza 2019, 276 pp.

3 A kötet a következő források alapján készült: MOLNÁR Margit (álnév): Napló. Msc.; MÁRKOSsY Klára (álnév): Napló. Budapest - Nyíregyháza 1944. december 24. - 1945. május 7. OSZK QH 3171; Fortepan. Lissák Tivadar fényképe (72925. sz.) 1944; BICSKEY Erzsébet: Napló. Harmadik füzet (1943. november 24. - 1946. március 3.); BoDÓ Róza: Napló. Második füzet (1945. június 13. - 1947. november 1.); A Szív. A Jézus Szíve Szövetség heti értesítője. 1945. július 21.
} 
Magyarországon, magyar katonák a megszállt Ukrajnában vagy amerikai katonák az általuk fenntartott menekülttáborokban), hanem a háború címú darab rendezői. Mert olyan darab ez, melyet nem szabadna kigondolni, megírni, finanszírozni, de végképp nem műsorra tűzni a történelem színpadán. Ha mégis így esett, hát legyen műfaja tragédia. Megtekintéséhez ajánlott a szóban forgó naplók szemüvege. E szemüveg egy helyet láttat, melyen jól kirajzolódik az emberi életkörülmények teljesen megváltozott állapota és folyamatos alakulása, embereket akik e kihívásoknak sem lelkiismeretükre hallgatva, sem azt ignorálva nem tudtak kielégítően megfelelni.

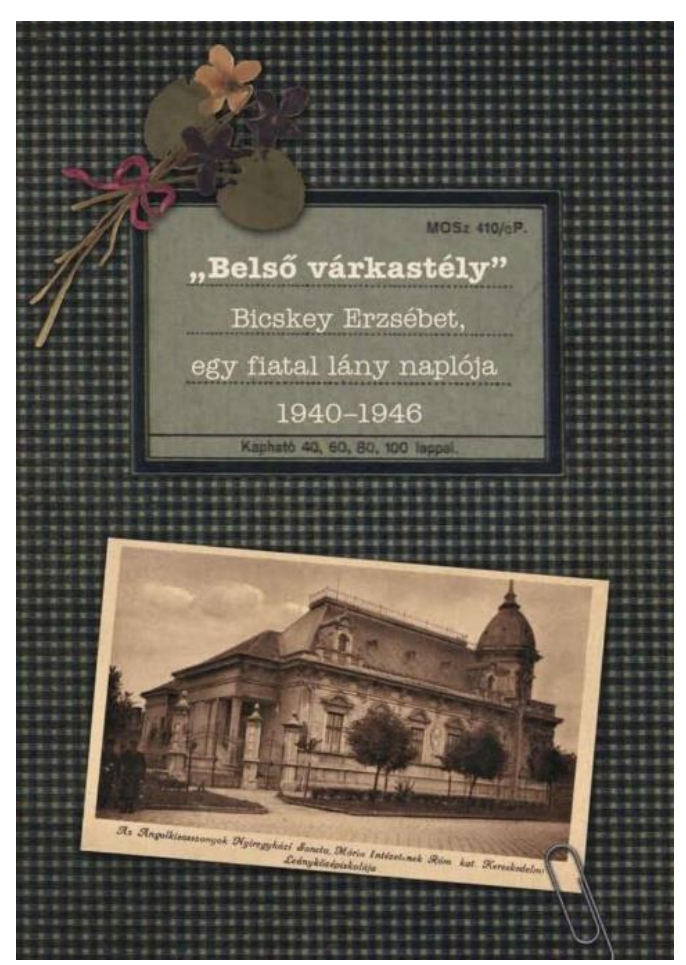

Látunk kispolgári környezetének mikrovilágából azt őt körülvevő makrovilág borzalmaira reagáló fiatal lányt, aki egyoldalúan szeret, ${ }^{4}$ és látunk anyát gyermekétől, feleséget férjétől elválasztva. Az itthon maradt nők szenvedéseit kiegészítendő, rövid bepillantást nyerünk az otthontól távol, a lelkiismeretével és az ellenséggel küzdő magyar férfi helyzetébe. Ez a forrás segít igazán megérteni azt is, hogy milyen lehetetlen helyzetben léteztek maguk a megszálló szovjet hadsereg katonái is, akiktől a naplóíró nők aztán a megismert borzalmakat elszenvedték. Ezzel persze nem menthetô semmilyen gonoszság, de a tézis áll: a háború nem embernek való léthelyzet.

Mindkét kötet, ha mégoly terhes olvasmányok is, rendkívül fontosak, hasznosak és tanulságosak. Annak pedig, hogy a belőlük levont következtetések milyen messzemenők, a szerzők nem szabnak gátat. Ez egyedül az olvasón múlik.

\footnotetext{
${ }^{4}$ A napló, melynek eseményei nagyrészt Nyíregyházához, kisebb részt Nyírbátorhoz és Budapest környékéhez kötődnek, 2008-ban egy lomtalanítás alkalmával került Szabó Piroska irodalomtörténész, az Országos Széchenyi Könyvtár későbbi könyvtárosa tulajdonába.
} 